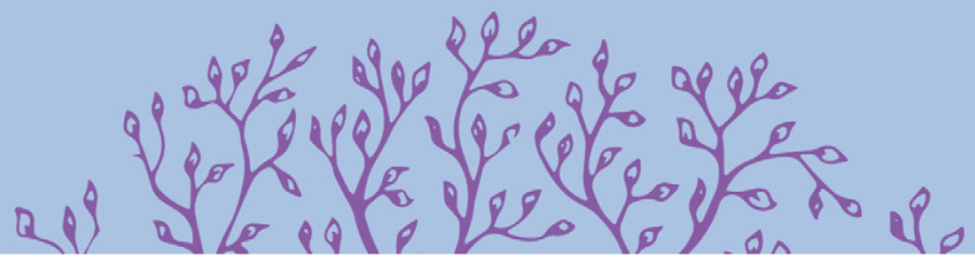

EMERALDHANDBOOKS

\title{
THE EMERALD HANDBOOK OF WOMEN AND ENTREPRENEURSHIP IN DEVELOPING ECONOMIES
}

\author{
EDITED BY \\ SHAHAMAK REZAEI \\ JIZHEN LI \\ SHAYEGHEH ASHOURIZADEH \\ VELAND RAMADANI \\ SHQIPE GËRGURI-RASHITI
}

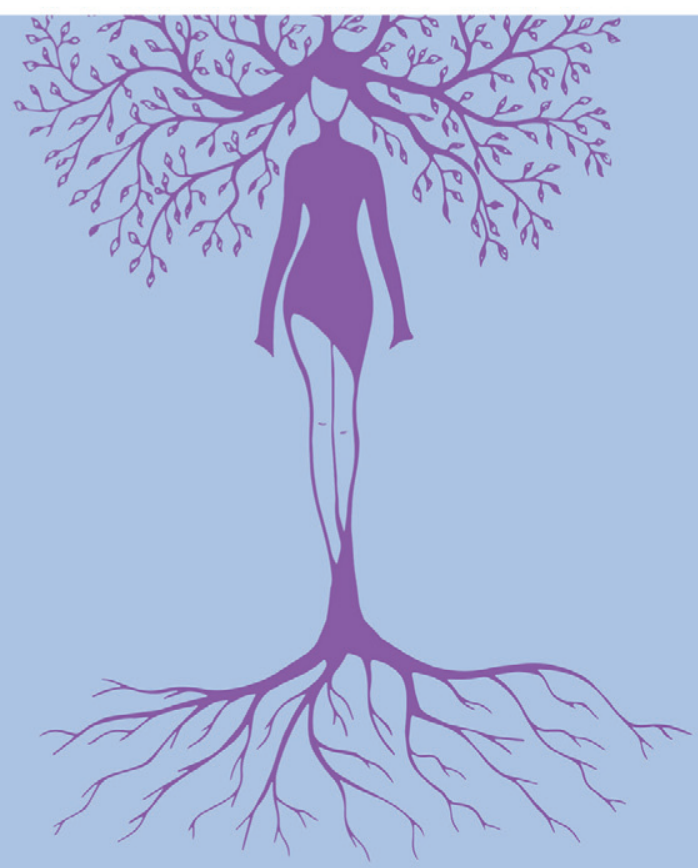


The Emerald Handbook of Women and Entrepreneurship in Developing Economies 
Since my original work in female entrepreneurship in the United States, one of the first academic articles on the topic, which was followed by numerous articles focusing on female entrepreneurs in various countries throughout the world and one book on the topic, I have concluded that the best outcomes occur when a strong, effective private sector of female entrepreneurs occurs. I commend the contributors of this work on women entrepreneurship in developing economies as they address an area that has not received the attention that has occurred in developed economies. After providing the reader with a conceptual understanding of the topic as well as gender differences and diversity, the book focuses on aspects of women entrepreneurs in specific countries (Latin America, Gulf Cooperation Council (GCC), and Kuwait, China, Kosovo, Modern Persian, Afghanistan, Iran, Turkey, the MENA and Nordic regions, and Pakistan). I know that as you read this book will appreciate and gain valuable insights on the role that over 163 million women entrepreneurs play in developing economies worldwide.

-Robert D. Hisrich, PhD

Bridgestone Professor of International Business, Director of the Global Management Center

Kent State University (USA)

This is a definitive contribution to our understanding of gender and entrepreneurship. Rezaei and his collaborators offer the first comprehensive assessment of the role of women in selfemployment and business formation in less developed countries. Of special interest is their focus on the relationship between women's economic activity and institutions. The book weaves a rich tapestry in which women come alive as agents of their own destiny, devising survival strategies but also ways to enhance businesses as they interact, often through contestation, with imperfect institutions. This is the best available portrayal of a subject as significant as it is timely.

-Patricia Fernández-Kelly, Professor of Sociology, Princeton University 
This book led by Shahamak Rezaei made an important contribution to the important research field of women entrepreneurship and emerging economies. The wide geographical coverage shows the prevailing issues and challenges that women entrepreneurs encounter in developing and growing their ventures. I highly recommend this book to students of entrepreneurship, international business, public policy, and organization studies.

-Prof. Dr. Yipeng Liu FAcSS

Professor in Management and Organisational Studies

Henley Business School

University of Reading, UK

Founding Director, China Management and Global Business

The Emerald Handbook of Women and Entrepreneurship in Developing Economies provides an insightful and complete review of all important aspects of female entrepreneurship in the setting of a developing country. The book investigates this increasingly important phenomenon from individual and institutional point of view. The reader will be able to grasp the motivation, main challenges, barriers, drivers, and opportunities for female entrepreneurs in certain developing economies of the Middle East and Northern Africa, Latin America, Europe, and Asia. Finally, the book provides significant review of the challenges imposed by COVID-19 pandemic on business activity of women entrepreneurs. Ultimately, the literature in this area gains valuable, multicultural, and contemporary contribution with this title.

-Dr. Vladimir Dzenopoljac

American University of the Middle East, Kuwait

Women's entrepreneurship is a rapidly growing phenomenon in developing economies. With the endless effort of the authors and editors during the COVID-19 pandemic, this book suggests a comprehensive analysis of the challenges and opportunities women entrepreneurs encounter in the process of entrepreneurship and, more importantly, how they emancipate in a dynamic environment full of uncertainties and gender disparities. Indeed, women entrepreneurs, experts, and policymakers can enjoy this research as it provides a foundation for understanding this phenomenon from multiple perspectives. This collection will be a valuable reference for students, educators, policymakers, and entrepreneurs.

-Dr. Ying Chen

School of Economics, Fujian Normal University, China 
This page intentionally left blank 


\section{The Emerald Handbook of Women and Entrepreneurship in Developing Economies}

EDITED BY

SHAHAMAK REZAEI

Roskilde University, Denmark

\section{JIZHEN LI}

Tsinghua University, China

\section{SHAYEGHEH ASHOURIZADEH}

Tsinghua University, China

\section{VELAND RAMADANI}

South East European University, North Macedonia

And

\section{SHQIPE GËRGURI-RASHITI}

American University of the Middle East, Kuwait
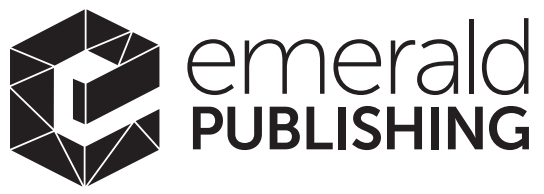

United Kingdom - North America - Japan - India - Malaysia - China 
Emerald Publishing Limited

Howard House, Wagon Lane, Bingley BD16 1WA, UK

First edition 2021

Copyright (C) 2021 by Emerald Publishing Limited

\section{Reprints and permissions service}

Contact: permissions@emeraldinsight.com

No part of this book may be reproduced, stored in a retrieval system, transmitted in any form or by any means electronic, mechanical, photocopying, recording or otherwise without either the prior written permission of the publisher or a licence permitting restricted copying issued in the UK by The Copyright Licensing Agency and in the USA by The Copyright Clearance Center. Any opinions expressed in the chapters are those of the authors. Whilst Emerald makes every effort to ensure the quality and accuracy of its content, Emerald makes no representation implied or otherwise, as to the chapters' suitability and application and disclaims any warranties, express or implied, to their use.

\section{British Library Cataloguing in Publication Data}

A catalogue record for this book is available from the British Library

ISBN: 978-1-80071-327-7 (Print)

ISBN: 978-1-80071-326-0 (Online)

ISBN: 978-1-80071-328-4 (Epub)

ISOQAR certified

Management System,

awarded to Emerald

for adherence to

Environmental

standard

ISOQAR

ISO 14001:2004. 


\section{Contents}

About the Contributors $x i$

List of Contributors $\quad x x i$

Foreword by Benson Honig $x x v$

Part 1: Conceptual Understanding of Woman Entrepreneurship in Developing Economies

Chapter 1 Women Entrepreneurship Footprints: Some Introductory Reflections from Emerging Economies Prospects

Shahamak Rezaei, Jizhen Li, Shayegheh Ashourizadeh, Veland Ramadani and Shqipe Gërguri-Rashiti

Chapter 2 Entrepreneurship and Innovation Emancipation among Women Entrepreneurs in Developing Countries

Huda Al Matroushi, Fauzia Jabeen, Sherine Farouk and Moza

Tahnoon Al Nahyan

Chapter 3 Gender Roles in Developing Countries and Women Entrepreneurs' Intention/Entry/Business Engagement and Performance

Hui Zhang and Xiaohu Zhou

Chapter 4 Gender Diversity, Environmental Performances, and the Role of Countries' Development Status 49

Mohamed M. Sraieb and Ahmet Akin 
Part 2: Institutions, History, Culture as Catalysator or Blockage for Woman Entrepreneurship

Chapter 5 Female Entrepreneurship in Latin America and the Key Role of Informal Institutions in the Reproduction of Gender Asymmetries

Shahamak Rezaei and Denise Helena França Marques

Chapter 6 Women Entrepreneurship in Developing Countries: With Focus on GCC and Kuwait

Shqipe Gërguri-Rashiti and Sareh Rotabi

Chapter 7 Exploring Contextual Influences on Women's Everyday Entrepreneuring: A Case from China

Ziyu Long

Chapter 8 The Role of Gender and Institutional Factors for Entrepreneurs and Corporate Entrepreneurs in Latin American Countries

Linda Elizabeth Ruiz, Elda Barron and José Ernesto Amorós

Chapter 9 Women Entrepreneurs and the Challenge of Work-Life Balance: Evidence from Kosovo Kaltrina Kajtazi

Chapter 10 The Institutional History of Women Entrepreneurship in Modern Persia: A Socio-historicism Approach Amir Forouharfar

Chapter 11 Female Entrepreneurship à Brasileira: Entrepreneurship by Choice or Entrepreneurship by Force?

Denise Helena França Marques, Nicia Raies Moreira de Souza and Shahamak Rezaei

Chapter 12 Women Entrepreneurship in Developing Countries: The Context of Afghanistan 
Chapter 14 Gendered Social Capital in Developing Countries: The Case of Turkey

Hiroko Kawamorita, Yashar Salamzadeh, Ali Kahramanoğlu, Kürşat Demiryürek, Nur İlkay Abacı and Noriyuki Takahashi

Part 3: Entrepreneurial Ecosystem and Female Digital Entrepreneurship

Chapter 15 Digital Natives' Entrepreneurial Mindset: A

Comparative Study in Emerging Markets

Piotr Kwiatek, Stavros Papakonstantinidis and Radoslav Baltezarevic

Chapter 16 Entrepreneurial Ecosystem and Female Digital Entrepreneurship - Lessons to Learn from an Iranian Case Study 317 Aidin Salamzadeh and Veland Ramadani

Chapter 17 Networking Activity of Female Entrepreneurs Over Time: An Exploratory Case Study on Female Entrepreneurs from Early-Stage to Establishment

Zahra Arasti, Elnaz Tarzamni and Neda Bahmani

Part 4: Early-stage Female Entrepreneurship, Drivers, and Outcomes

Chapter 18 Lessons from Global Financial Crisis: Human Capital and Business Activities among Nascent Women Entrepreneurs in China

Shayegheh Ashourizadeh and Chuqing Zhang

Chapter 19 Innovation Amplifies Growth Ambitions of Early-Stage Female Entrepreneurs: More in Nordics, Less in MENA Region

Mehrzad Saeedikiya, Zeynab Aeeni, Serdar Temiz and Hiroko Kawamorita

Chapter 20 Empowering Women through Microfinance Banks in Rural Areas of Pakistan

Salman Bashir Memon and Claire Seaman 
This page intentionally left blank 


\section{About the Contributors}

Nur İlkay Abacı is a PhD Research Assistant in the subdepartment of Agricultural Policy and Extension in the Department of Agricultural Economics, Faculty of Agriculture, Ondokuz Mayıs University, Samsun, Turkey. She got MSc about Rural Women Entrepreneurship from Tokat Gaziosmanpaşa University. She did her PhD from Agricultural Policy and Extension Department of Ondokuz Mayis University, Samsun. She PhD thesis was about "Farmers' Decision Making Process on Product Pattern: The Case of Vegetable Growers in Bafra District of Samsun Province of in Turkey." She has nine years professional experience and conducted research in rural women entrepreneurship, factors affecting microcredit adoption by rural women, organic agriculture, and good agriculture. She has also worked as a researcher in projects such as TUBITAK, BAP, DOKAP in Turkey. She is also an academic advisor in a student project.

Zeynab Aeeni holds a PhD in Entrepreneurship from University of Tehran, and currently, she is a Lecturer of Entrepreneurship at Kurdistan University, Iran. Zeynab is interested in researching entrepreneurship, institutions, gender, and sustainability. Zeynab formerly has published in Journal of Entrepreneurship in Emerging Economies, MENA Journal of Cross-Cultural Management, and European Research on Management, Business and Economics.

Abdulbari Ahmadzai is an Assistant Professor at Kabul University, Faculty of Economics. Previously, Assistant Professor at Jahan University, Faculty of Economics. In addition, from 2014 to 2016, he served as tax vocational trainer and audit general manager in the Ministry of finance. He optioned MA in Economics from Yamaguchi University, Japan and a Bachelor in Economics from Herat University, Afghanistan. His research interest is in macroeconomics, public finance, and entrepreneurship. He has researched in "Factors, which have impact on Households income in Paktia province" and "The impact of tax audit on tax compliance and revenue generation in Afghanistan."

Ahmet Akin received his PhD in Finance from Istanbul University, Turkey. He
gained research experience as a visiting scholar in the School of Management at
Syracuse University, US. He served at several universities in different countries.
He most recently worked as an Associate Professor of Finance at the American
University of the Middle East, Kuwait. He has published in leading business
journals including Emerging Markets Finance and Trade, International Business
Review, and Journal of International Studies. His research interests include firm 
performance, capital structure, corporate social responsibility, market risk assessment, bankruptcy estimation, and behaviors of investors.

Dr Huda Al Matroushi is a Member of the Abu Dhabi Business Women Council, Owner and Chairman of Ancestors Heritage Factory, and Partner in Food and Beverage (Saj Al Feerej, Chocolate Republic, Salad Boutique, and Baeet Omai) and the founder of the Emarat Al Mutakamela for retired people. She is a Doctoral Graduate of the College of Business, Abu Dhabi University (ADU).

José Ernesto Amorós is Professor and Doctoral Programs Director at EGADE Business School, Tecnológico de Monterrey, Mexico. Until December 2015, he was the Executive Director of the Entrepreneurship Institute at Universidad del Desarrollo, Chile. He holds a PhD in Management Sciences from ESADE Business School. He has a Bachelor's Degree in Business Administration and MSc in Marketing from Tecnológico de Monterrey, Mexico. He is a Member of several academic organizations and VP of Iberoamerican Academy of Management. His research interests are entrepreneurship and competitiveness, high growth new business, entrepreneurship, and gender and corporate entrepreneurship.

Zahra Arasti is an Associate Professor of Entrepreneurship at the University of Tehran. Her research and teaching span women's entrepreneurship, social entrepreneurship, and entrepreneurship education programs. She publishes in premier journals, in English, French, and Persian.

Shayegheh Ashourizadeh is a Research Fellow at the Research Center of Technological Innovation at Tsinghua University, China. She received her Postdoc in Entrepreneurship and Business in 2020 from the School of Economics and Management, Tsinghua University. She employs quantitative and qualitative research methodologies to scrutinize small business and entrepreneurship phenomena and better understand the economic decision-making, psychological and institutional underpinnings. She has presented her works at international conferences, including AoM, RENT, Babson, and Druid. Her recent works are published in international journals, including the International Entrepreneurship and Management Journal, European Journal of International Management, International Journal of Business and Globalization, International Journal of Entrepreneurship and Small Business, and Gender in Management.

Neda Bahmani graduated from the Faculty of Entrepreneurship, University of Tehran. Her research interest is women's entrepreneurship and entrepreneurship education programs. She designs entrepreneurship programs at Hormozgan Science and Technology Park (Iran).

Radoslav Baltezarevic is an Associate Professor in Marketing, Communication, and Media at the Cyprus International Institute of Management, Nicosia, Cyprus. He worked before that as a HOD and Professor in Marketing, Communication and Media at the College for Communications in Belgrade. Since 2018, he has been an Academic Member of Athens Institute for Education, and prior to that, he worked as an Associate Professor at the University College of Bahrain, Assistant Professor at the American University of the Middle East in 
Kuwait, and Assistant Professor at the Faculty of Business Economy and Entrepreneurship in Belgrade. He is a well-rounded researcher with nearly 90 publications, published in national and international journals and scientific conferences.

Elda Barron is an Assistant Professor and Researcher of Entrepreneurship and Innovation at Universidad de Monterrey (Mexico). She holds a $\mathrm{PhD}$ in Business Administration from EGADE Business School, Tecnologico de Monterrey. Her research interests include Science-based Entrepreneurship and Entrepreneurship Education. Also, she is a Consultant and Entrepreneurship Mentor.

Nicia Raies Moreira de Souza is Social Scientist with master's and doctorate in Sociology from the Federal University of Minas Gerais, is a Researcher at João Pinheiro Foundation since 1994, has experience in research management households and data analysis, and works in the area of inequality and social stratification studies; labor market, youth, and gender.

Kürşat Demiryürek is a Professor in Ondokuz Mayıs University (OMU), Samsun, Turkey. He got BSc on Agricultural Economics and MSc on Rural Distance Education both from Ankara University, PhD from Agricultural Extension and Rural Development Department of Reading University, England. He has professional experiences in rural extension, innovation systems, social network analysis, organic agriculture, rural distance education, and entrepreneurships, and worked in several FAO, UNDP, WB, and EU projects. He is an Editor of Journal of Agricultural Extension and Rural Development and also established préincubation and informatics centers for entrepreneurship and coordinated entrepreneurship and innovation programmes at OMU. More info available at: https://personel.omu.edu.tr/en/kursatd, https://www.researchgate.net/profile/Kursat_ Demiryurek

Dr Sherine Farouk joined the faculty of the College of Business at ADU in 2007. Before joining ADU, she was the Assistant Professor at the London School of Economics and Arab Academy for Science and Technology. Dr Sherine taught training courses in Accounting, Finance, and Management fields in many organizations worldwide. Sherine received the "Best Paper Award" in different international conferences for her research. She has a vibrant and high ranked intellectual contribution in the area of Accounting, Finance, Sustainability, and Innovation. Dr Sherine is also part of the editorial board of different Scientific Journals.

Amir Forouharfar received his Bachelor's Degree in English Language and Literature from Arak University. He graduated as an honor student both for a Master's Degree in Entrepreneurship Management and a $\mathrm{PhD}$ in Public Administration from University of Sistan and Baluchestan. His main areas of research are entrepreneurship, organization theory, public administration, and philosophy. His key areas of expertise include strategic entrepreneurship, organization theory development, and philosophical epistemology. Dr Forouharfar has over 30 fully refereed articles in prestigious journals, conferences, and books. Currently, he is coediting several book titles on strategic entrepreneurship and COVID-19 repercussions in state administration with Springer. 
Shqipe Gërguri-Rashiti is an Associate Professor at the American University of the Middle East, Kuwait - currently serving as the Dean of the College of Business Administration. Shqipe has very diverse education background in different international institutions which can be a great asset for an academic, with excellent communication, decision-making, planning, and organizing skills with strong touch of personal and professional integrity. She has a unique experience in living and working in diverse cultural environments worldwide. Her research interests are on female entrepreneurship, innovation, technology, and strategic management based on which she has written and coauthored papers focused in these areas. She published research articles in journals such as Strategic Change: Briefings in Entrepreneurial Finance (UK), European Journal of Social Sciences (UK), and International Bulletin of Business Administration (UK).

Fauzia Jabeen is a Professor of Management at the College of Business at Abu Dhabi University, UAE. She has published in leading journals like International Journal of Hospitality Management, Knowledge Management Research \& Practice, Journal of Cleaner Production, Food Quality and Preferences, International Journal of Productivity and Performance Management, International Journal of Organizational Analysis, Gender in Management: An International Journal. She has been honored with the "Outstanding Paper Award" and "Highly Commended Paper" in the 2018 and 2019 Emerald Literati Awards, Abu Dhabi University Research Fellow Award 2018. She can be reached at fauzia.jabeen@adu.ac.ae.

Ali Kahramanoğlu works as an Assistant Professor at Ondokuz Mayıs University, Bafra Faculty of Business Administration. He received his $\mathrm{PhD}$ in accounting and finance. He teaches undergraduate and graduate courses in the field of entrepreneurship. His main areas of expertise are accounting, finance, banking, and insurance, and he is engaged in academic studies in entrepreneurship and innovation.

Kaltrina Kajtazi holds the position of Lecturer in the Department of Business and Management at the Universum College in Prishtina, Kosovo. In terms of her education, she completed her Bachelor Studies at the University of Prishtina, in the Department of Management and Informatics, Faculty of Economics, with a maximum average, being selected the most distinguished student of the generation. She obtained a Master's Degree in Human Resource Management from City College, the International Faculty of the University of Sheffield, in Thessaloniki, Greece. She is currently pursuing a $\mathrm{PhD}$ in Business Administration at the South East European University in Tetovo, North Macedonia.

Hiroko Kawamorita is a Lecturer of Entrepreneurship, as well as creating and implementing international projects at Ondokuz Mayis University. Her research interests include Entrepreneurial University, Media Entrepreneurship, and Rural Women Entrepreneurship. She holds a Master of Business Administration from Cardiff Metropolitan University, UK, studied and worked in different countries for over 20 years including Italy, Iran, Turkey, Jordan, Maldives, Tunisia, Malta, and Japan. She is the Editor in Chief for International Journal of Economics \& 
Strategic Management of Business Process, as well as the International Journal of Business \& Economic Strategy. She was recently appointed as an academic coordinator at Global Education Career Center, UK.

Piotr Kwiatek is the Head of Marketing Department at American University of the Middle East (Kuwait) and a former member of the Faculty of Management at Poznan University of Economics and Business (Poland). He holds the Certified Management and Business Educator (Chartered ABS) qualification and graduated Artificial Intelligence and Machine Learning program at McCombs Business School (University of Texas at Austin). His research concentrates on customer relationship management, loyalty programs, and sales management. He authored over 50 articles in refereed journals, and recognized business outlets. Piotr is a cofounder of Global Sales Science Institute and Centrum B2B.

Jizhen Li is the Professor of Innovation and Entrepreneurship Management at Tsinghua University School of Economics and Management (SEM). He is also the Associate Dean of Tsinghua SEM. He holds a PhD (2002) in Management Science, a MA in Management Science, and BE (1997) both in Automobile Engineering and Industrial Engineering from the Tsinghua University. He visited MIT Sloan School of Management as an International Faculty Fellow for half a year in 2006. He teaches courses such as Management of Technological Innovation, Innovation Research Seminar, Technological Entrepreneurship, and Project Management. His research interests include management of technological innovation, strategic management, and project management. As Principal Investigator, he has finished or is working on many projects, including six research projects funded by the National Science Foundation (NSF) of China. His research has appeared in Administrative Science Quarterly, Information and Management, Journal of Management, Research Policy, R\&D Management, and Strategic Management Journal.

Ziyu Long (PhD, Purdue University) is an Assistant Professor of Organizational Communication in the Department of Communication Studies at Colorado State University, US. Her research interests include career, entrepreneurship, work-life negotiation, and workplace resistance and resilience. Her work has appeared in such outlets as Management Communication Quarterly, Journal of Applied Communication, Gender, Work \& Organization, Journal of Business and Technical Communication, Journal of Business and Entrepreneurship, as well as a number of edited books and conference proceedings.

Denise Helena França Marques is an economist, $\mathrm{PhD}$ in demography and Researcher at João Pinheiro Foundation (FJP), Brazil. She has experience in the areas of social indicators, human development, data analysis, components of demographic dynamics and labor market. She is currently Principal Research Coordinator of the Population Studies Center of Fundação João Pinheiro and member of the Brazilian Association of Population Studies.

Salman Bashir Memon, $\mathrm{PhD}$, is Chairman of the Department of Business Administration at Shaheed Benazir Bhutto University, Shaheed Benazirabad. His 
current research interests include knowledge management, work-life balance, workplace diversity, work design, mixed-methods research, and structural equation models. He earned his doctoral degree in management science from Queen Margaret University in Musselburgh, Scotland.

Meisam Modarresi is an Assistant Professor of Entrepreneurship at University of Semnan. He received his PhD and Master's Degree in entrepreneurship from the University of Tehran. His research interests include Academic Entrepreneurship, Women Entrepreneurship, and Home Business. Dr Modarresi's research has been published in several peer-reviewed journals including Gender in Management and International Journal of Gender and Entrepreneurship. He also has several published books and book chapters in Persian.

Zabihullah Modaser is Associate Professor at Faculty of Economics, Kabul University since 2001. He obtained his Master's Degree of Art in Development Management from Ruhr University Bochum - Germany. His Bachelor's is in economics from Kabul University. Currently, he is working on his $\mathrm{PhD}$ in philosophy of accounting in International Islamic University of Malaysia. Beside academic tasks, Mr. Modaser has practical experience in management, accounting, and finance since he worked with international NGOs such as USAID. His some papers are published in academic magazine of economics faculty.

Dr Moza Tahnoon Al Nahyan is a Professor of Management at the College of Business at ADU, where she teaches management principles to business students. She has published her research works in international refereed journals and has received the "best paper award" in international conferences. She is also an entrepreneur and philanthropist and is known for her various charitable activities in the community.

Ahsanullah Mohsen is Assistant Professor at Kabul University, Faculty of Economics. Previously, he was Assistant Professor in Economics Department and head of research and publication committee at the faculty of Economics, Kardan University. Previously, he worked as academic vice chancellor at Jahan University, Kabul. He obtained Master of Science in Management and Economics from Ruhr University Bochum, Germany and a Bachelor in Business Management from Goa University, India. "Technical Efficiency of Fruit Production in Afghanistan" and Employee participation in decision-making and its effect on job satisfaction are his recent published article in IEE, Ruhr University Bochum, and Asian Journal of Technology Management, respectively. Furthermore, he is the coauthor of a book chapter "Entrepreneurship in Emerging Economies: A Contextualized Approach (Edward Elgar Publishing).”

Stavros Papakonstantinidis is an Associate Professor at the American University of the Middle East in Kuwait with more than 15 years of multicultural academic and professional experience in strategic communications, public relations, and advertising. He is a published author of two books in New York, multiple peer-reviewed journal papers and book chapters, and an appointed researcher and country expert for labor market studies conducted by Cedefop and Eurostat. He 
is a Doctor of Social Sciences from the University of Leicester, UK, specializing in Social Media Recruiting and Digital Natives. He holds an MSc in Strategic Communication from Ithaca College and a BA in Organizational Communication from the State University of New York, US.

Veland Ramadani is a Professor of Entrepreneurship and Family Business at the Faculty of Business and Economics, South East European University, North Macedonia. His research interests include entrepreneurship, small business management, and family businesses. He authored or coauthored around 140 research articles, 11 textbooks, and 18 edited books. He has published in Journal of Business Research, International Entrepreneurship and Management Journal, International Journal of Entrepreneurial Behavior \& Research, Technological Forecasting and Social Change, among others. Dr Ramadani is Editor-in-Chief of the Journal of Enterprising Communities (JEC). He has received the Award for Excellence 2016 - Outstanding Paper by Emerald Group Publishing. In addition, Dr Ramadani was invited as a keynote speaker in several international conferences and as a guest lecturer by President University, Indonesia and Telkom University, Indonesia. In 2017, he was appointed as a member of the Supervisory Board of Development Bank of North Macedonia, where for ten months served as an acting Chief Operating Officer (COO) as well.

Shahamak Rezaei obtained his $\mathrm{PhD}$ in Business Administration, with focus on Network Theory and Entrepreneurship, from the University of Southern Denmark. He is currently Associate Professor at the Department of Social Sciences and Business, Roskilde University, Denmark. He consults Nordic Governments (Nordic Council of Ministers) and international organizations (OECD, EU REA). Further, he is affiliated with Sino-Danish Center (SDC) for Education and Research, which is the flagship in Science Diplomacy between the Danish government and the Chinese government. In his SDC activities, he focuses on "Innovation Management" research groups where he since 2010 has been conducting research and heading research teams between Chinese and Danish scholars. He is also affiliated as Non-Resident Research Associate at Princeton University, Office of Population Research (OPR), Center for Migration and Development (CMD), where he collaborates with colleagues at Princeton on STEM (Science, Technology, Engineering, and Math) - Migration and Global Talent Mobility. He is the winner of "Danske Bank" 2014 award in "Social Innovation \& Social Entrepreneurship" (September 19, 2014). He has also been appointed as one of the most influential persons in immigration and integration issues in Denmark in the magazine EUROMAN (February 2006, p. 49). Dr Rezaei's research focuses on Transnational Knowledge Transfer, Migration, Global Entrepreneurship, Transnational Entrepreneurship, and Diaspora Entrepreneurship. He is Research Coordinator for the research project "DiasporaLink," financed by the European Commission (EU REA) under "Horizon 2020 - RISE Program."

Sareh Rotabi is an Executive Manager of Investor Relations and Development at Human Soft Holding Company in Kuwait. She is an experienced economist with 
a demonstrated history of working in Higher Education, management and financial services. She has participated in several international and domestic conferences as well as an academic student exchange program in France. Her research interests are Macroeconomics and Macroeconomic policies, Entrepreneurship, and Happiness.

Linda Elizabeth Ruiz is a Professor in the Business School at Tecnologico de Monterrey in Mexico. She holds a PhD in Business Administration. Her central area of study is oriented to the entrepreneurial and innovative behavior that occurs within established organizations. She has deepened to study the influence of external factors over the activity. She is particularly interested in the study of entrepreneurial behavior from a gender perspective. Moreover, she seeks to analyze the implications of the activity over the regions. She has collaborated with researchers in other areas like entrepreneurial education and regional development.

Mehrzad Saeedikiya is based at the Center of Future Enterprise (CFE) at Queensland University of Technology, Brisbane, Australia. Formerly, he has had some teaching and research positions at University of Tehran, University of Milan, and Tsinghua University. Mehrzad is interested in researching entrepreneurship and innovation in the context of institutions. He has published some piece of research in European Journal of International Management, Journal of Entrepreneurship in Emerging Economies and MENA Journal of Cross-Cultural Management.

Yashar Salamzadeh is a PhD scholar in Human Resources Management and is a Senior Lecturer in Graduate School of Business at Universiti Sains Malaysia. He has published more than 100 research articles in international and national journals and conferences. He has the experience of eleven years teaching in MBA and Master of management courses in five different universities. He has supervised more than 70 graduate students (On MBA and Master level) in their thesis and dissertation and is supervising $8 \mathrm{PhD}$ and DBA students as well. He has developed many managerial workshops on leadership, social entrepreneurship, HRM, Business models in different countries such as Iran, Turkey, Russia, Malaysia, Hungary and UK. He has worked as a project management in many national and international research projects. He has the experience of five years management consultancy for different public and private organizations on Leadership, Organizational restructuring, EFQM, Culture, HRM systems, Organizational behavior. He also has cooperated in more than twenty international journals as an editorial board member and review board member. $\mathrm{He}$ is also an EFQM auditor. He has served GSB as Head of "Global Strategy and Organizational Behavior" research cluster since 2018. He is leading the microcredential initiative of GSB as well. His fields of interest include entrepreneurship, Entrepreneurial Universities, Leadership and digital leadership, business models, strategic management, green business and CSR, HRM (HCM) and networked organizations. Yashar can be contacted using below emails: yashar@usm.my or yasharsalamzadeh@gmail.com. 
Aidin Salamzadeh is an Assistant Professor at the Faculty of Management, University of Tehran. He has several publications in journals such as Journal of Economic Psychology, Journal of Enterprising Communities, Journal of Enterprising Culture, and International Journal of Entrepreneurship and Small Business. His main areas of interest are contextual entrepreneurship, start-ups, new venture creation, media entrepreneurship, and social entrepreneurship. He serves as an editor, a member of the editorial board of journals such as The Bottom Line (Emerald), and $S A G E$ Open (Sage), as well as a reviewer in a series of distinguished international journals such as Baltic Journal of Management, Journal of Small Business and Enterprise Development (Emerald), Journal of Cleaner Production (Elsevier), Canadian Journal of Administrative Sciences (Wiley), and Economic Research (Taylor \& Francis). He is also a member of the European SPES Forum (Belgium), the Asian Academy of Management (Malaysia), Institute of Economic Sciences (Serbia), and Ondokuz Mayis University (Turkey).

Dr Claire Seaman holds the Chair in Enterprise and Family Business at Queen Margaret University in Edinburgh, Scotland. She has published extensively in the field of family businesses research, in the UK, New Zealand, Canada, Asia, Jordan, and Latin America, and is a regular contributor to family business conferences worldwide. Her books include Corporate Citizenship and the Family Business (Greenleaf, an imprint of Routledge, forthcoming) and The Modern Family Business, published by Palgrave McMillan. Claire maintains close links with the business community and business organizations such as Family Business United Scotland and local economic development agencies. She is a frequent speaker at gatherings of family businesses and professional advisors. This interaction enables her to share insights from evidence-based research with practitioners, while ensuring that her research focuses on areas of importance to the family business and entrepreneurship communities. Her current research interests include work on family business, business start-up, and entrepreneurship in a variety of contexts and cultures, including work in Scotland, the Basque Region of Spain, Malaysia, Ghana, Jordan, Pakistan, Nepal, and Uzbekistan.

Mohamed M. Sraieb holds a PhD in Economics from the European Center for Advanced Research in Economics and Statistics (ECARES), Université libre de Bruxelles. Mohamed is currently Assistant Professor at American University of the Middle East, Kuwait. Formerly, he was Assistant Professor of Economics at University of Essex, UK. Mohamed is an applied economist. He carries out research at ECARES where he is an associate fellow. His research interests include macroeconomics, international trade, development economics, and quantitative methods. He is particularly interested in exploring the microfoundations of development strategies, trade policies, and environmental negotiations.

Noriyuki Takahashi is a Vice President at Musashi University, Tokyo, Japan. He is also the leader of the GEM Japan team. He obtained his Bachelor of Economics from Keio University, Tokyo, Japan, then a Master of Business Administration from Babson College, Wellesley, US. Besides, he has worked over 20 years at Japan Finance Corporation prior to his Professorship Appointment at the University. 
Elnaz Tarzamni is an Independent Researcher in entrepreneurship from the Faculty of Entrepreneurship, University of Tehran, Iran. She is interested in research in the field of women's entrepreneurship.

Serdar Temiz is a Researcher and Lecturer at the Industrial Engineering and Management Division of Uppsala University, Sweden. His research and lectures focus on open innovation, business models, entrepreneurship, and new product development in different industries and contexts.

Hui Zhang is a PhD Candidate in the School of Economics and Management at Nanjing University of Science and Technology, and she was born in Anhui province, China. She has a one-year visiting scholar experience at University of Southern Denmark. Her research interests cover women entrepreneurship and entrepreneurial emotion. Her work has appeared in Chinese management studies and leading Chinese business journals. Moreover, her recent work is being reviewed by Entrepreneurship Theory and Practice.

Chuqing Zhang received her PhD degree from Tsinghua University, P.R. China. Now, she works in Economic Research Institute, Beijing Language and Culture University. Her research interests include project evaluation, technology innovation, and machine learning.

Xiaohu Zhou is a $\mathrm{PhD}$ and a Professor of Economics and Management of Nanjing University of Science and Technology, a Professor of Jiangsu Talent Research Institute, and a doctoral tutor. His research interests cover corporate strategic management, entrepreneurial management, and talent management. His works have been published by Journal of Business Ethics, Chinese Management Studies, Frontiers in Psychology, International Journal of Social Behavior and Personality. He also published his researches in top Chinese journals. 


\section{List of Contributors}

Nur İlkay Abacı

Zeynab Aeeni

Abdulbari Ahmadzai

Ahmet Akin

Huda Al Matroushi

José Ernesto Amorós

Zahra Arasti

Shayegheh Ashourizadeh

Neda Bahmani

Radoslav Baltezarevic

Elda Barron

Nicia Raies Moreira de Souza

Kürşat Demiryürek

Sherine Farouk

Amir Forouharfar

Shqipe Gërguri-Rashiti

Benson Honig

Fauzia Jabeen

Ali Kahramanoğlu

Kaltrina Kajtazi

Hiroko Kawamorita
Ondokuz Mayıs University, Turkey

University of Kurdistan, Iran

Kabul University, Afghanistan

American University of the Middle East, Kuwait

Abu Dhabi University, UAE

Tecnológico de Monterrey, Mexico

University of Tehran, Iran

Tsinghua University, China

Hormozgan Science and Technology Park, Iran

Cyprus International Institute of Management, Cyprus

Universidad de Monterrey, Mexico

João Pinheiro Foundation, Brazil

Ondokuz Mayıs University (OMU), Turkey

Abu Dhabi University, UAE

University of Sistan and Baluchestan, Iran

American University of the Middle

East, Kuwait

McMaster University, Canada

Abu Dhabi University, UAE

Ondokuz Mayıs University, Turkey

Universum College in Prishtina, Kosovo

Ondokuz Mayıs University, Turkey 
Piotr Kwiatek

Jizhen $\mathrm{Li}$

Ziyu Long

Denise Helena França

Marques

Salman Bashir Memon

Meisam Modarresi

Zabihullah Modaser

Moza Tahnoon Al Nahyan

Ahsanullah Mohsen

Stavros Papakonstantinidis

Veland Ramadani

Shahamak Rezaei

Sareh Rotabi

Linda Elizabeth Ruiz

Mehrzad Saeedikiya

Yashar Salamzadeh

Aidin Salamzadeh

Claire Seaman

Mohamed M. Sraieb

Noriyuki Takahashi

Elnaz Tarzamni

Serdar Temiz
American University of the Middle East, Kuwait

Tsinghua University School of Economics and Management (SEM), China

Colorado State University, USA

João Pinheiro Foundation (FJP), Brazil

Shaheed Benazir Bhutto University,

Shaheed Benazirabad, Pakistan

University of Semnan, Iran

Kabul University, Afghanistan

Abu Dhabi University, UAE

Kabul University, Afghanistan

American University of the Middle East, Kuwait

South East European University, North Macedonia

Roskilde University, Denmark

Human Soft Holding Company, Kuwait

Tecnológico de Monterrey, Mexico

Queensland University of Technology, Australia

Universiti Sains Malaysia, Malaysia

University of Tehran, Iran

Queen Margaret University, United

Kingdom

American University of the Middle East, Kuwait

Musashi University, Japan

University of Tehran, Iran

Uppsala University, Sweden 
Hui Zhang

Chuqing Zhang

Xiaohu Zhou
Nanjing University of Science and Technology, China

Beijing Language and Culture University, China

Nanjing University of Science and Technology, China 
This page intentionally left blank 


\section{Foreword}

This handbook makes a valuable contribution by uniquely combining three exciting and relevant arenas of research: (1) entrepreneurship promotion, (2) gender studies, and (3) emergent economies. It is highly relevant to scholars, policymakers, and practitioners, alike. While considerable work has examined these issues separately, the bulk of existing research focuses on advanced economies, and is often phenomenologically driven. This is problematic because institutional and cultural barriers to entrepreneurship, and particularly to women entrepreneurs, often tend to be more constrained in emergent economies. As well, this work arrives during an important time of transition - as the world experiences a global pandemic, the nature of work, as well as previously well-established cultural norms, expectations, and career trajectories are upturned and revised. These transitions present important opportunities for entrepreneurs, particularly more marginalized persons including women, to adapt to new constraints with ingenious and unexpected innovations.

As the work in this handbook illuminates, cultural variations may play a more extensive role in either facilitating or hampering women entrepreneurs than other factors often examined by entrepreneurship scholars, highlighting an important research gap often overlooked in the literature. As well, much scholarship continues to focus on the economic contributions that entrepreneurs make, frequently overlooking their social contributions, a characteristic that has been associated with gender and offers an important distinction when examining issues of community development.

Professor Rezaei and his colleagues have amassed an important contribution to the literature that firmly anchors their work in a reframing of the "entrepreneurship for economic development" narrative. They span multiple levels (e.g. individual and institutional/national) highlighting the need for contextual understanding of these phenomenons. Their focus includes not only life-cycle factors, but also historical, cultural, and regional specificities that provide important generalizable insight when we move outside the heavily research environments of Europe and North America.

Scholars who have worked in entrepreneurship over the past few decades fully recognize the importance of gender studies, including feminist perspectives on social change and development. From a relatively marginalized perspective, the field has grown with important scholarship, including its own prestigious international annual scholarly conference (the Diana International Research Conference, associated with the Diana Project). Much work continues to focus on 
inequality in advanced economies, including gender biases that impact venture capital and other financial support, industry location, leadership, limited growth and/or market capitalization, and a dearth of suitable role models, particularly in STEM or in fortune 500 companies. However, our knowledge of entrepreneurial pursuits in emergent economies is less complete.

I found the work in this handbook to be both unique and valuable, providing important insights into contexts and regions previously overlooked. How, for example, does entrepreneurship innovation intersect with gender roles? Little is known regarding female entrepreneurship in regions such as Iran, China, and Afghanistan, where exceptional cultural and institutional factors are likely to strongly impact entrepreneurial opportunities for women. This handbook provides an important collection of unique insights, handily collated into one significant volume. I'm certain to utilize this handbook in my own scholarly research as well as in the classroom, and I salute professor Rezaei and his colleagues for carefully providing this important addition to my library shelf. I'm sure you'll agree.

Benson Honig

Teresa Cascioli Chair in Entrepreneurial Leadership DeGroote School of Business, McMaster University Hamilton, Ontario, Canada 26, October 2020 


\section{Part 1}

\section{Conceptual Understanding of Woman Entrepreneurship in Developing Economies}


This page intentionally left blank 


\title{
Chapter 1
}

\section{Women Entrepreneurship Footprints: Some Introductory Reflections from Emerging Economies Prospects}

\author{
Shahamak Rezaei, Jizhen Li, Shayegheh Ashourizadeh, \\ Veland Ramadani and Shqipe Gërguri-Rashiti
}

\begin{abstract}
Women Entrepreneurship has received increasing attention over the past decade. In particular, a new area dealing with women entrepreneurs in the developing societies. The aim of this study is how is women entrepreneurship in developing economies? More specifically, we are excavating various questions at the individual and institutional level. The results of this study contribute to understanding the importance of the context on women entrepreneurs' activities. Additionally, it systematically provides a comprehensive framework at multilevel analyses to cover all aspects of women entrepreneurship in developing countries. Ultimately, knowing women entrepreneurship in developing countries helps policymakers provide a firm ground for self-employment of women.
\end{abstract}

Keywords: women entrepreneurship; developing context; culture;

entrepreneurship barriers; female entrepreneurial activities; analytical Levels

\section{Introduction}

Earlier twenty-first-century scholars have tapped on women entrepreneurship in the United States and Europe (Brush, 1992; De Bruin, Brush, \& Welter, 2006; Hughes, Jennings, Brush, Carter, \& Welter, 2012). In this regard, publications try to explore women entrepreneurship at the individual, organizational, and environmental levels (Brush, Carter, Gatewood, Greene, \& Hart, 2006) and compared women entrepreneurs' resources, such as human and social capital, and their performance with their counterparts (Wadhera \& Koreth, 2012). Studies have also investigated the propensity of women engagement in the entrepreneurial

\footnotetext{
The Emerald Handbook of Women and Entrepreneurship in Developing Economies, 3-12 Copyright $@ 2021$ by Emerald Publishing Limited All rights of reproduction in any form reserved doi:10.1108/978-1-80071-326-020211001
} 
process in different countries (Minniti \& Nardone, 2007; Terjesen, 2004) and how they overcome barriers to entrepreneurial activities (Fielden \& Davidson, 2005). During the last five years, frontiers in women entrepreneurship have noticed the stimulating effect of context and ecosystem on women's entrepreneurial activities (Manolova, Brush, Edelman, Robb, \& Welter, 2017). Also, how it may enhance or impede their performance (for example, Guelich, Bullough, Manolova, \& Schjoedt, 2021; Birkner, Ettl, Welter, \& Ebbers, 2018; Blackburn, Hytti, \& Welter, 2015) in developed countries like the United States.

Though the literature has advanced our knowledge in women entrepreneurship in developed countries, there is a paucity of research in developing countries (Yadav \& Unni, 2016). There are 137 countries with a GNI of US \$11,905 or less that are counted as developing countries and carrying $90 \%+$ of the world's population, and half of this population consists of women. (Singhal \& Khadilkar, 2014). Worldwide experience advocates that economic growth will happen through more substantial support for women to contribute to the economy. Thus, it is merit to investigating women entrepreneurship in developing countries for two reasons:

(1) Over 163 million women pursue entrepreneurial activities worldwide (Global Entrepreneurship Monitor, 2017), which shows women entrepreneurs' significant contribution to the economy. Recent reports on women's entrepreneurial endeavors (Global Entrepreneurship Monitor, 2017) have revealed that women's Total Entrepreneurial Activity (TEA) rate has increased in all 74 countries. The Global Entrepreneurship Monitor (GEM) has reported the highest rising-rate women's role in TEA in developing countries by $15.1 \%$ in 2017-18. Women have surpassed men's TEA in developing regions such as Asia (Philippines and Vietnam) and Latin America (Mexico and Brazil), where the gender gap is an institutional challenge.

(2) Developing countries are a matter of interest since their context includes traditional, incomplete, and unstable institutions (Gaur, Kumar, \& Singh, 2014) that affect entrepreneurial activities and entrepreneurs' behaviors. However, prior research has not unveiled the impact of such institutions on especially women entrepreneurs and how they face various challenges that are different from developed countries (Coad \& Tamvada, 2012; Manolova, Carter, Manev, \& Gyoshev, 2007). For instance, how women entrepreneurs struggle with these institutions and construct new values and structure in those societies (Ahl, 2006) to achieve success is yet unknown.

However, very few studies have considered this category. One of the closest research studies is the book on Female Entrepreneurship in Transition Economies, edited by Ramadani, Gërguri-Rashiti, and Fayolle (2015). Other works are about solo-country cases; for instance, some scholars have come up to publish books about countries like India (Jamil, 2019), China (Sun \& McLean, 2019), and Iran (Sarfaraz, 2017). Though studies have improved our understanding of women entrepreneurship in developing countries, it lacks comprehensive research to give insights into women's entrepreneurial behavior and understanding to policymakers to design and deliver initiatives that truly exploit women entrepreneurs' economic growth potentials. 


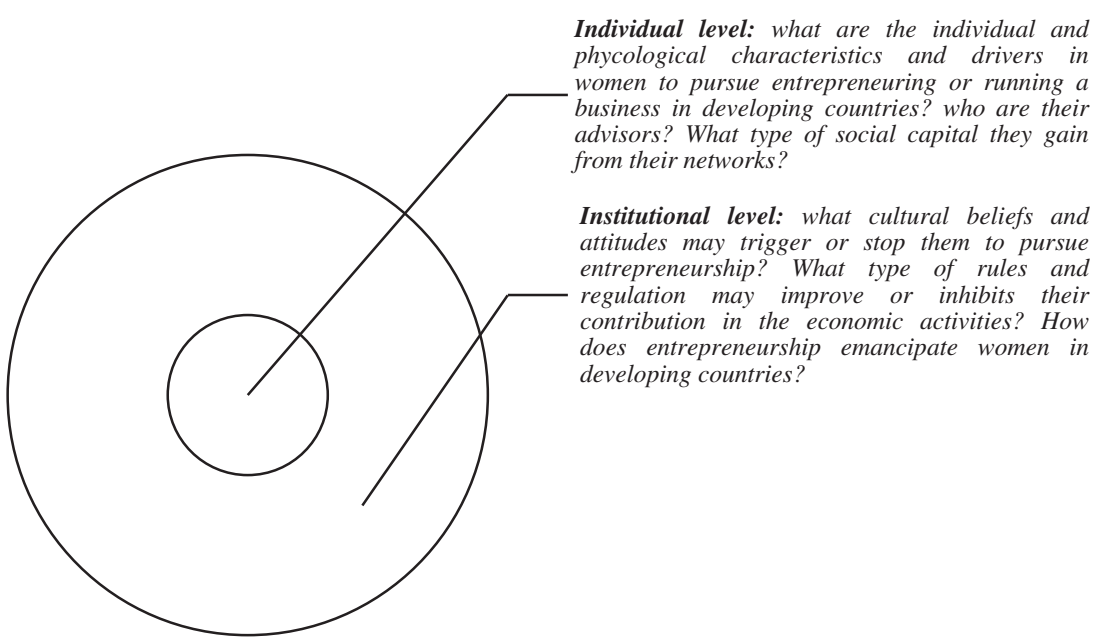

Fig. 1.1. Women Entrepreneurship in Multilevels of Analysis.

Thus, the purpose of this book is to investigate women entrepreneurship in a multilevel analysis. We are about to answer the general research question that How is women entrepreneurship in developing economies? More specifically, we are excavating various questions at the individual and institutional level. Fig. 1.1 illustrates some of the specific research questions at each level.

At the individual level, understanding the nature, aspirations, human and social capitals, psychological derivers, and barriers in such societies may help us to explain the high rate of entrepreneurial activities among women in developing countries.

At the institutional level, drawing upon the institutional view (North, 1990), which consists of formal and informal institutions, it is interesting to know how different policies, rules, and regulations in developing countries affect women entrepreneurs' outcomes and overcome difficulties hindering institutions.

We believe that working on women entrepreneurship in developing countries is an excellent opportunity to contribute to this field. First, it sheds light on women entrepreneurship in a new context that has been called for research by scholars in women entrepreneurship (e.g., Jennings, Jennings, \& Sharifian, 2016; De Bruin et al., 2006). It also provides an opportunity to comprehensively study women entrepreneurship and enable scholars to compare and contrast among different countries and explain the psychological, sociological, and institutional mechanisms that enhance entrepreneurship among women in these societies.

Second, it systematically provides a comprehensive framework at multilevel analyses to cover all aspects of women entrepreneurship in developing countries. Such a framework provides a vivid picture of women entrepreneurship in developing countries, which can help prospective women entrepreneurship scholars position their research correctly in this area. 
Last but not least, this research provides fruitful knowledge for policymakers and practitioners. Knowing women entrepreneurship in developing countries helps policymakers provide the ground for self-employment of women when the unemployment rate is higher for women than men (in 2017, the global unemployment was $6.2 \%$ women and $5.5 \%$ men) and in times of crises. It is specifically noticeable after the COVID-19 pandemic. Women-dominated industries like day cares, education, and other service industries have been some of the most disrupted, and many working mothers have found their work disrupted to stay home. This has led to an unprecedented shock to women's employment by severe uncertainties regarding when businesses might return to normal operations and whether those jobs and the income they imply might still be there.

Understanding women entrepreneurship in developing countries also assists policymakers both in developed and developing countries. In developing countries, they may become aware of the gender gap in the entrepreneurship ecosystem and introduce better policy practices from developed countries to solve these issues. In developed countries, policymakers may inspire women entrepreneurs in developing countries and find solutions to improve the entrepreneurship rate among women in these societies, declining in recent years (Global Entrepreneurship Monitor, 2017).

\section{Structure of the Book}

The Emerald Handbook of Women and Entrepreneurship in Developing Economies covers various topics in women entrepreneurship from the gender perspective and institutional view. It includes understanding women's emancipation and empowerment, gender roles, firm performance, digitalization, barriers, and challenges of existing institutions in developing countries. This book represents a comprehensive state-of-the-art picture of women entrepreneurship issues. It provides significant theoretical and empirical evidence that is likely to offer a brighter view of this area from the gender and institutional view.

This work is an outcome of all contributors' long-lasting effort during one of the rough times of human history (COVID-19 pandemic). It includes contributions of highly reputed authors and experts of developing economies. According to the levels of analyses, this book has been divided into four parts, namely: (1) Conceptual Understanding of Woman Entrepreneurship in Developing Countries; (2) Institutions, History, Culture as catalysator or blockage for Woman Entrepreneurship; (3) Entrepreneurial Ecosystem and Female Digital Entrepreneurship; and (4) Early-stage Female Entrepreneurship, Drivers, and Outcomes.

Part I - Conceptual Understanding of Woman Entrepreneurship in Developing Countries - is followed by a chapter about Entrepreneurship and Innovation Emancipation among Women Entrepreneurs in Developing Countries that has been prepared by Huda Al Matroushi, Fauzia Jabeen, Sherine Farouk, and MOZA BINT TAHNON BIN MOHAMED ALNAHYAN. It discusses encouraging innovation in Small and Medium Enterprises (SMEs), one of the government's main policy initiatives at the local, regional, and national levels in the United 
Arab Emirates (UAE). This study's primary purpose is to explore the innovation characteristics, challenges, and factors influencing innovation in the Emirati female-owned nascent, start-up, and established SMEs. The analysis reveals that respondents believed in a strong vision, education, and risk-taking attitude as an innovative entrepreneur's essential characteristics. This study's findings will help policymakers and business women's councils identify the specific inhibitors and facilitators linked to innovation. The results will help develop various effective policies to promote innovation among Emirati women-owned SMEs.

The next chapter is entitled Gender Roles in Developing Countries and Women Entrepreneurs' Intention/entry/Business Engagement and Performance written by Hui Zhang and Xiaohu Zhou. They have conducted a systematic literature review on female entrepreneurship. The authors answer this question of how gender role works in developing countries and especially its influence on female entrepreneurs' intention/entry/business participation and performance. While women entrepreneurship is designated as the new economic growth engine in developing countries, prior research shows how men and women differ in starting a business. Women usually are facing more restrictions on entrepreneurial financing, entrepreneurial growth, and entrepreneurial performance. Gender roles have often explained this, yet there is still a lack of systematic understanding of how gender roles impact women's entrepreneurial processes in developing countries.

In Gender Diversity, Environmental Performances and the Role of Countries' Development Status by Mohamed M. Sraieb and Ahmet Akin, they investigate the relationship between gender diversity on corporate boards and firms' environmental performances. The central focus is the extent to which a country's economic status (developed, developing) can shape such a relationship. They found evidence that gender diversity is positively correlated to the environmental performances of firms. Interestingly, this correlation is stronger in developing countries and is also increasing in gender diversity. Such benefits can be a leverage for an efficient implementation of the United Nations Sustainable Development Goals (UN-SDGs), both as gender diversity stands as a goal by itself and facilitates achieving other environmental-related SDGs.

Part II is Institutions, History, Culture as catalysator or blockage for Woman Entrepreneurship that is opened up by a chapter about Female Entrepreneurship in Latin America and the Key Role of Informal Institutions in the Reproduction of Gender Asymmetries written by Shahamak Rezaei and Denise Helena França Marques. This chapter is a comprehensive overview of institutional factors in Latin America and how such institutions may constrain exploitation opportunities. The literature review showed how informal institutions, impregnated by patriarchal and macho culture, shape and determine gender relations in the world of work in the region, especially in women's business activities. Although the cases presented cannot be generalized to all Latin American countries, they provide a small sample of the obstacles, challenges, and limitations imposed on female entrepreneurs by the social structure and its repeated practices consolidated in Latin American society.

The following chapter, Women Entrepreneurship in Developing Countries: With Focus on GCC and Kuwait is contributed by Shqipe Gerguri-Rashiti and Sareh 
Rotabi. This chapter defines women entrepreneurship's role in developing countries in general, emphasizing GCC countries. It also introduces trends and challenges women entrepreneurs face, incentives to start their businesses, the support mechanism provided for them, the common conditions for women entrepreneurship, and women entrepreneurs' profiles in the GCC and Kuwait. The chapter also covers the impacts of the COVID-19 crisis on entrepreneurship (SMEs) along with the country policy responses to mitigate these impacts and ends with sharing useful recommendations on what needs to be taken into consideration in the future for the development of women entrepreneurship in general and more specifically within GCC countries and Kuwait.

Ziyu Long authored Exploring Contextual Influences on Women's Everyday Entrepreneuring: A Case from China. This chapter uses women entrepreneurs' entrepreneurial experiences in urban China as an empirical case to discuss contextual influences on women's everyday entrepreneurial experience in developing countries. Based on thematic analysis of women's own accounts of their entrepreneurial experiences, four societal influences emerged: (1) pre-entrepreneurial work experience, (2) national entrepreneurial development, (3) cultural values, and (4) gendered work ideology. These influences shaped and were shaped by women's entrepreneurial identities, decisions, and actions in situated contexts.

Linda Elizabeth Ruiz, Elda Barron, and José Ernesto Amorós have studied The Role of Gender and Institutional Factors for Entrepreneurs and Corporate Entrepreneurs in Latin-American Countries. Applying the data from the GEM, the Heritage Foundation and the World Bank, the authors attempted to disclose the women entrepreneurs' characteristics and behaviors in 10 Latin American countries. The results show that antecedents of entrepreneurship activity differ by gender. Specifically, the effect is different when analyzing labor regulations. We also find different intensity depending on gender.

The chapter Women Entrepreneurs and the Challenge of Work-Life Balance: Evidence from Kosovo is authored by Kaltrina Kajtazi. This chapter aims to answer three fundamental questions: do women entrepreneurs face difficulties in work-life balancing? Do they involve other family members in business operations to help work-life balance? and Is their marital status a factor in work-life balance? Through a qualitative research method, the author has found that most women entrepreneurs face difficulties in work-life balance. However, to overcome this challenge, they engage their family members in business activities. Also, married women, especially those with more than one child, have more difficulties in this aspect than those unmarried.

Amir Forouharfar has contributed to the chapter titled The Institutional History of Women Entrepreneurship in Modern Persia: A Socio-Historicism Approach. Through a historical approach, the author explores the gender institutions in Persia. Thus, the chapter first sets the historical context in each period and then sheds light on each period's women's pivotal issues. The undergirding base of the discussions assumes the change in institutions as natural metamorphosis in the animate. Finally, the discussions contribute to the conceptualization of the Institutional Triangulation and in the case of Persia. A cultural-driven triangulation has paved the way to forming a stupendously hegemonic patriarchal and masculine sociopolitical economy in Persia, 